\title{
Determination of Regularities in the Development of Intermodal Hubs' Planning Structure in «Smart» Cities
}

\author{
Denis Vlasov ${ }^{* 1,2}$ and Anna Terekhova ${ }^{1,3}$ \\ ${ }^{1}$ Moscow State University of Civil Engineering, Yaroslavskoe shosse, 26, Moscow, 129337, Russia \\ ${ }^{2}$ State Autonomous Institution «Research and Project Institute of General Planning for the city of \\ Moscow» \\ ${ }^{3}$ Research and Design Institute for Urban Planning
}

\begin{abstract}
This article is an attempt to determine regularities in the development of transport and transfer hubs. One of the components of the "smart city" concept is the "smart transport". The development of the transport system of a locality is one of the cornerstones for sustainable development of the urban territory, creating comfortable environment for human activities. The transport and transfer hub is the reference point of interaction between the urban environment and the transport infrastructure. When elaborating urban planning documentation for transfer hubs, special focus shall be made on the creation of comfortable and safe environment using the Transit Oriented Development (TOD) principles. At present, in Russia, the baseline document for territorial planning, which determines the limit parameters of the planned territory development, is the planning design. In Moscow and Moscow region, audacious transfer hub development programs have been adopted. Still, the regulatory and procedural framework for transfer hub planning is currently at the stage of elaboration. The goal of this study is to ascertain regularities between relevant and anticipated features of transfer hubs, based on approved hub plans in Moscow region. In particular, to reveal the dependence between the sizes of commercial areas making part of a hub, and the passenger traffic volume. The study uses the statistical method of regression analysis, which allows determining the function between dependent and independent variables. The model obtained can subsequently be used to calculate the limit parameters of the hub territory development, both at the stage of creating the hub development concept, and at the planning stage, to make well-grounded decisions as to limit parameters of the development.
\end{abstract}

\section{Introduction}

The organization of state-of-the-art transport systems as part of the "smart city" concept implies the extension of intermodal public trips. The term "intermodal" is understood as a trip using several kinds of public transport, or personal and public transport. The

*Corresponding author: vlasych@mail.ru 
development of intermodal transfers is impossible without development of the transport system's nodal points - transport and transit hubs (TTH) [1, 2, 3, 4 et al.].

To ensure maximum comfort, convenience and safety of passengers travelling through transfer hubs, standard development requirements, i.e. the statutory framework for urban planning of transfer hubs, shall be put in place. The elaboration of regulations and guidelines requires a wide range of research to be conducted, in particular, the detection and study of regularities between the hubs' objective and planned parameters.

The key objective of this paper is the exploration of dependences between a TTH's objective parameters and projected performance. The study is based on approved hub planning designs in Moscow region.

Till 2030, in Moscow region, 120 TTH projects will be implemented. The list of transfer hubs is approved by Decree of Moscow Region Government dated March 20, 2014 № 168/9 «On transfer hub development in Moscow region» [5] (fig. 1). Till 2021, in Moscow, about $147 \mathrm{TTHs}$ will be created [6]. Intermodal transfer hub programs are implemented by the Russian Railways JSC, and by a number of Russia's biggest cities (Saint Petersburg, Kazan, etc.).

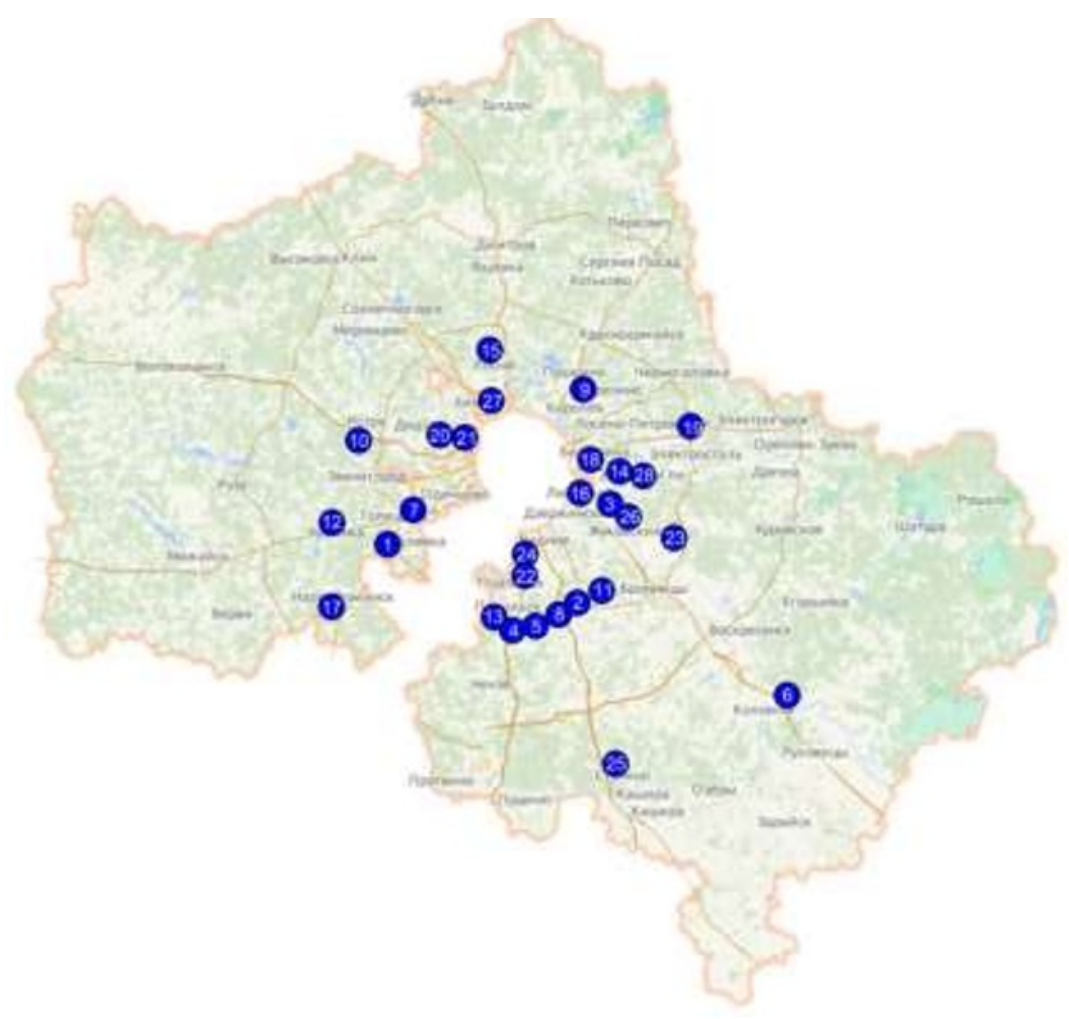

Fig. 1. Location of transfer hubs considered by this paper

1) Aprelevka 2) Bolshoe Domodedovo 3) Bykovo 4) Vesennyaya 5) VSM Podolsk 6) Golutvin 7) Zhavoronki 8) Ivanovka 9) Ivanteevka-2 10) Istra 11) Konstantinovo 12) Kubinka 1 13) Kuznechiki 14) Kupavna 15) Lobnya 16) Lyubertsy-1 17) Nara 18) Nikolskoe 19) Noginsk 20) Opalikha 21) Pavshino 22) Podolsk 23) Ramenskoe 24). Silikatnaya 25) Stupino 26) Udelnaya 27) Khimki 28) Elektrougli 
TTH urban planning standards are incorporated in a small section of guidelines 42.13330.2016 under Construction regulation 2.07.01-89* [7], and in some individual references made in regional urban planning standards [8, 9, 10 et al.]. Currently, the Institute for General Planning of Moscow has prepared the "Transport and transfer hubs" guideline, to be approved in 2019 [11, 12].

Table 1. Characteristics of transport and transfer hubs in Moscow region

\begin{tabular}{|c|c|c|c|c|c|c|c|c|c|}
\hline \multirow[b]{2}{*}{ No } & \multirow[b]{2}{*}{$\begin{array}{c}\text { Name of } \\
\text { TTH }\end{array}$} & \multirow[b]{2}{*}{$\begin{array}{c}\text { TTH } \\
\text { territory } \\
\text {, ha }\end{array}$} & \multicolumn{3}{|c|}{ Projected TTH characteristics } & \multirow[b]{2}{*}{$\begin{array}{c}\text { Passenger } \\
\text { traffic }{ }^{3}, K \\
\text { persons/morning } \\
\text { peak hour }\end{array}$} & \multirow[b]{2}{*}{$\begin{array}{c}\text { Distance } \\
\text { from } \\
\text { MRR, } \\
\text { km }\end{array}$} & \multirow[b]{2}{*}{$\begin{array}{c}\text { Travel } \\
\text { time } \\
\text { to } \\
\text { MRR, } \\
\text { min }\end{array}$} & \multirow[b]{2}{*}{\begin{tabular}{|c} 
TTH \\
influence \\
zone $^{4}$, ha
\end{tabular}} \\
\hline & & & $\begin{array}{c}\text { Process } \\
\text { area } \\
\text { thousand } \\
\text { m }^{2}\end{array}$ & $\begin{array}{c}\text { Commercial } \\
\text { area, } \\
\text { thousand } \\
\text { m }^{2}\end{array}$ & $\begin{array}{c}\text { Total } \\
\text { thousand } \\
\mathbf{m}^{2}\end{array}$ & & & & \\
\hline 1 & \begin{tabular}{|l|} 
Kuznechiki \\
\end{tabular} & 3.80 & 24.48 & 49.40 & 73.88 & 4.20 & 19.00 & 75 & 645.00 \\
\hline 2 & Vesennyaya & 5.00 & 24.80 & 43.90 & 68.70 & 2.80 & 21.70 & 55 & 723.00 \\
\hline 3 & VSM Podolsk & \begin{tabular}{|l|l|}
$\mathrm{k}$ & 10.00 \\
\end{tabular} & 9.00 & 35.10 & 44.10 & 4.90 & 19.50 & 45 & 640.00 \\
\hline 4 & \begin{tabular}{|l|} 
Bolshoe \\
Domodedovo
\end{tabular} & 9.00 & 48.10 & 199.80 & 247.90 & 1.50 & 28.20 & 25 & 508.00 \\
\hline 5 & Konstantinovd & 9.00 & 31.00 & 239.40 & 270.40 & 2.00 & 20.00 & 40 & 638.00 \\
\hline 6 & Ivanovka & 7.00 & 15.80 & 88.90 & 104.70 & 1.50 & 24.20 & 45 & 482.00 \\
\hline 7 & Ramenskoe & 3.70 & 17.00 & 50.39 & 67.39 & 2.30 & 26.50 & 80 & 505.00 \\
\hline 8 & Golutvin & 3.79 & 4.80 & 70.00 & 74.80 & 7.50 & 87.00 & 115 & 507.00 \\
\hline 9 & Kupavna & 3.22 & 9.70 & 4.40 & 14.10 & 3.70 & 17.50 & 55 & 820.00 \\
\hline 10 & Opalikha & 2.98 & 3.90 & 3.50 & 7.40 & 4.20 & 9.00 & 80 & 901.00 \\
\hline 11 & Kubinka 1 & 1.41 & 12.55 & 2.50 & 15.05 & 3.80 & 47.30 & 45 & 1200.00 \\
\hline 12 & Elektrougli & 2.53 & 12.30 & 3.80 & 16.10 & 2.50 & 22.80 & 70 & 970.00 \\
\hline 13 & Zhavoronki & 1.70 & 3.30 & 1.50 & 4.80 & 2.17 & 20.00 & 80 & 470.00 \\
\hline 14 & \begin{tabular}{|l|} 
Ivanteevka-2 \\
\end{tabular} & 0.90 & 1.40 & 1.50 & 2.90 & 2.70 & 14.50 & 35 & 390.00 \\
\hline 15 & Istra & 3.46 & 2.65 & 12.00 & 14.65 & 0.43 & 34.70 & 50 & 350.00 \\
\hline 16 & Lobnya & 2.90 & 3.00 & 10.00 & 13.00 & 8.35 & 12.30 & 25 & 993.00 \\
\hline 17 & Lyubertsy-1 & 4.30 & 11.40 & 140.28 & 151.68 & 3.05 & 4.80 & 30 & 535.00 \\
\hline 18 & Nikolskoe & 1.79 & 4.80 & 0.50 & 5.30 & 3.10 & 3.50 & 15 & 481.00 \\
\hline 19 & \begin{tabular}{|l} 
Pavshino \\
\end{tabular} & 4.83 & 2.40 & 3.60 & 6.00 & 14.23 & 4.00 & 50 & 1690.00 \\
\hline 20 & Udelnaya & 1.26 & 3.80 & 1.90 & 5.70 & 0.82 & 15.30 & 50 & 427.00 \\
\hline 21 & Podolsk & 3.80 & 1.82 & 8.40 & 10.22 & 9.21 & 16.10 & 35 & 884.00 \\
\hline 22 & Nara & 2.69 & 4.00 & 2.00 & 6.00 & - & 53.70 & 70 & 472.00 \\
\hline 23 & Silikatnaya & 4.85 & 0.60 & 4.80 & 5.40 & - & 12.10 & 45 & 694.00 \\
\hline 24 & \begin{tabular}{|l} 
Noginsk \\
\end{tabular} & 2.76 & 2.55 & 0.33 & 2.88 & - & 38.60 & 55 & 480.00 \\
\hline 25 & \begin{tabular}{|l} 
Stupino \\
\end{tabular} & 4.42 & 2.67 & 44.00 & 46.67 & - & 78.40 & 65 & 1600.00 \\
\hline 26 & Khimki & 3.04 & 12.40 & 7.20 & 19.60 & - & 1.35 & 15 & 1260.00 \\
\hline 27 & Aprelevka & 3.15 & 5.90 & 7.60 & 13.50 & - & 26.70 & 70 & 718.00 \\
\hline 28 & Bykovo & 1.87 & 4.62 & 3.00 & 7.62 & - & 17.10 & 55 & 490.00 \\
\hline
\end{tabular}

\section{Notes:}

- ${ }^{1}$ The TTH territory shall mean the zone of projected deployment of TTH facilities (including " $2 \mathrm{D}$ " facilities, commercial facilities, etc.);

- $\quad{ }^{2}$ Process facilities ensure the formation of the TTH transport component and the operation of various kinds of transport systems;

- $\quad{ }^{3}$ Passenger traffic is the aggregate volume of passenger boarding to and deboarding from all modes of transport, interacting within a TTH;

- $\quad{ }^{4}$ Zone of influence is the territory from which the passengers can access the transfer hub.

Moreover, certain procedures shall be elaborated, governing the transfer hub formation, based in particular on the study and systematization of existing solutions approved by administrative documents. We have examined and analyzed a number of approved hub layout designs in Moscow region prepared in the last few years, in order to determine the regularities in the anticipated development of transport and transfer hubs. 


\section{Methods}

Public data of approved TTH territory planning designs in Moscow region will be used as the source material for the study. Currently, 28 transfer hub planning designs have been approved (fig. 1).

The objective of the study is to reveal presence (or absence) of dependences between TTHs' objective parameters and projected performance characteristics. One of the possible approaches is the statistical method considering the influence of any one or several independent variables upon a dependent variable - the regression analysis [13, 14, 15 et al.]. The regression analysis allows determining the dependent variable's values using the independent variable.

In our study, the general population are transfer hubs in Moscow region with approved layout designs.

To conduct a regression analysis, we will draw a summary table (table 1) with quantitative values, which will be checked for the existence of any dependence. The following dependent variables shall be included in the table:

- TTH's parameters defined in administrative acts, subject to the functional purpose of areas and territories;

- Passenger traffic, calculated pursuant to the predicted use of various modes of transport, and subject to the additional load from the TTH's commercial component.

And independent variables:

- $\quad$ Territory occupied by the TTH;

- $\quad$ Distance from the TTH to Moscow Ring Road (MRR);

- Travel time by personal transport from the hub to the MRR

- Area of the TTH's influence zone.

The objective of this paper is the study of dependences between projected and objective TTH parameters, therefore, we use the planned territory area to estimate the distribution within the general population, as it is the most objective indicator of a TTH's role and importance. Calculations were made which showed that, within the general population, the TTH distribution follows the normal law, which allows the study to be conducted.

\section{Results}

All possible kinds of indicators' dependences on each other were examined: 28 cases in all. It is ascertained that in 10 cases, there is a function between the indicators. Further, the graphic functions where checked for stochastic dependences by regression analysis.

The calculations made have shown that the existing dependences are polynomial. Polynomial functions have the following form:

where: $x$ - independent variable;

$$
y=a+b_{1} x+b_{2} x^{2}+\cdots+b_{n} x^{n}
$$

$y$ - dependent variable;

$a$ - free term of the estimation line. This is the value of $y$, when $x=0$;

$b$ - angle factor. This factor shows $y$ 's increase with increasing $x$. 
As the paper considered dependences between two variables, the following condition shall be met: the number of examined factors of every one independent variable shall be above 10 , but below 100 .

Upon completion of the regression analysis, the final table was drawn, containing the values of all coefficients.

When performing the regression analysis, we should first of all focus on the $\mathrm{R}$ square (determination) coefficient. The higher is the coefficient, the most accurate and precise is the model. If the $\mathrm{R}$ square coefficient is under 0.5 , the regression analysis is deemed unreasonable.

The first value of $Y$-crossing shows what will be the $\mathrm{Y}$ value, if all $\mathrm{X}$ variables in the model are equal to zero.

The variable coefficient $X 1$ shows the weight of $\mathrm{Y}$ variable's influence upon the $\mathrm{X}$ variable. The sign preceding the coefficient shows the type of dependence (direct or inverse).

Pursuant to the results of the regression analysis, $R$-square is above 0.5 in the following dependences of functional and layout elements:

- Dependence of the projected commercial zone area on the TTH territory area is exponential, regression equation: $y=0,2335 x^{2}+16,463 x-31,812$;

- Dependence of the influence zone area on the passenger traffic is polynomial, regression equation: $y=4 E-06 x^{2}+0,0002 x+1,537$;

- Dependence of the sum of commercial and process zone areas on the TTH territory area is polynomial, regression equation: $y=0,368 x^{2}+17,829 x-$ 29,858;

- Dependence of the commercial zone area on the process zone area is polynomial, regression equation: $y=0,031 x^{2}+3,1178 x-0,7703$;

Table 2. Dependence of the commercial zone area on the TTH territory area

Totals output

\begin{tabular}{|l|r|}
\hline \multicolumn{2}{|c|}{ Regression statistics } \\
\hline Multiple R & $\mathbf{0 , 7 1 9 3 8 0 2 1 7}$ \\
\hline R-square & $\mathbf{0 , 5 1 7 5 0 7 8 9 7}$ \\
\hline Normalized R-square & 0,498950508 \\
\hline Standard error & 43,44642543 \\
\hline Observations & 28 \\
\hline
\end{tabular}

Variance analysis

\begin{tabular}{|c|c|c|c|c|c|}
\hline & $d f$ & $S S$ & $M S$ & $F$ & F relevancy \\
\hline Regression & 1 & 52639,07 & 52639,07 & 27,88689 & $1,6 \mathrm{E}-05$ \\
\hline Excess & 26 & 49077,39 & 1887,592 & & \\
\hline Total & 27 & 101716,5 & & & \\
\hline & Coefficients & Standard error & t-statistics & $P$-value & Bottom 95\% \\
\hline Y-crossing & $-36,79892865$ & 16,23 & $-2,26734$ & 0,031915 & $-70,1602$ \\
\hline X 1 variable & 18,96536878 & 3,591379 & 5,280804 & $1,6 \mathrm{E}-05$ & 11,58318 \\
\hline
\end{tabular}




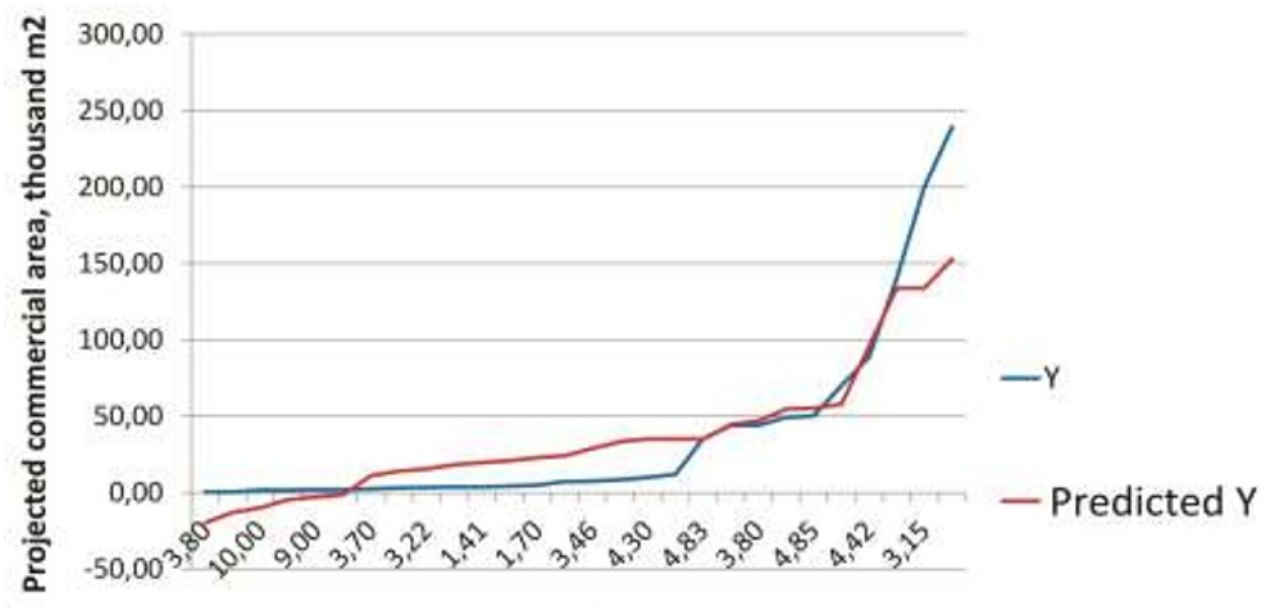

TTH territory area, ha

Fig. 2. Dependence of projected commercial area on the TTH territory area

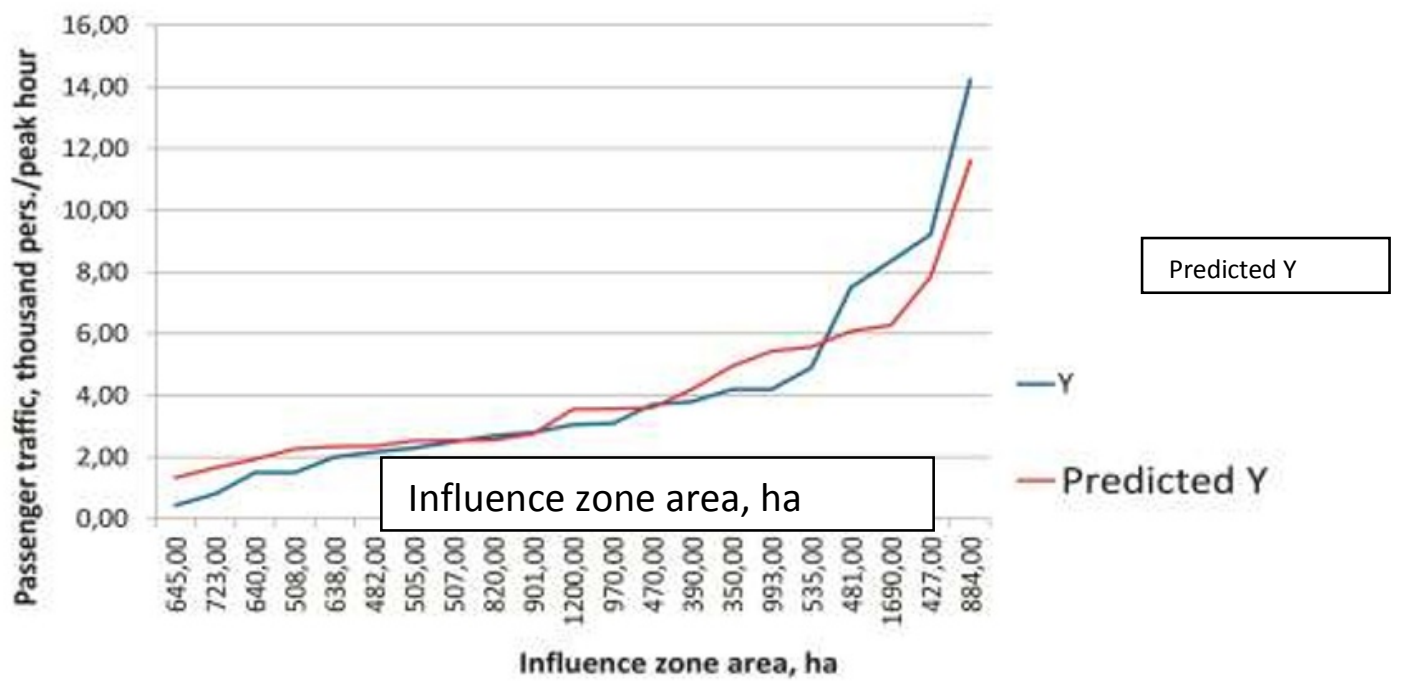

Fig. 3. Dependence of the influence zone area on the passenger traffic 


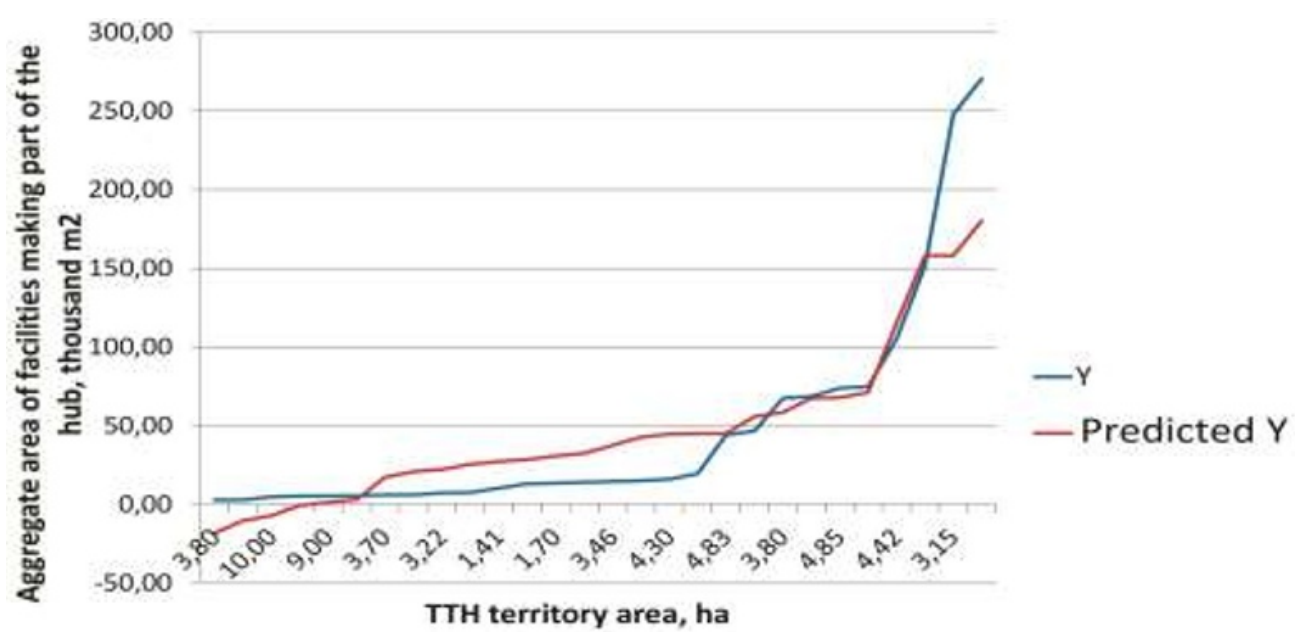

Fig. 4. Dependence of the aggregate area of facilities making part of the hub on the TTH territory area

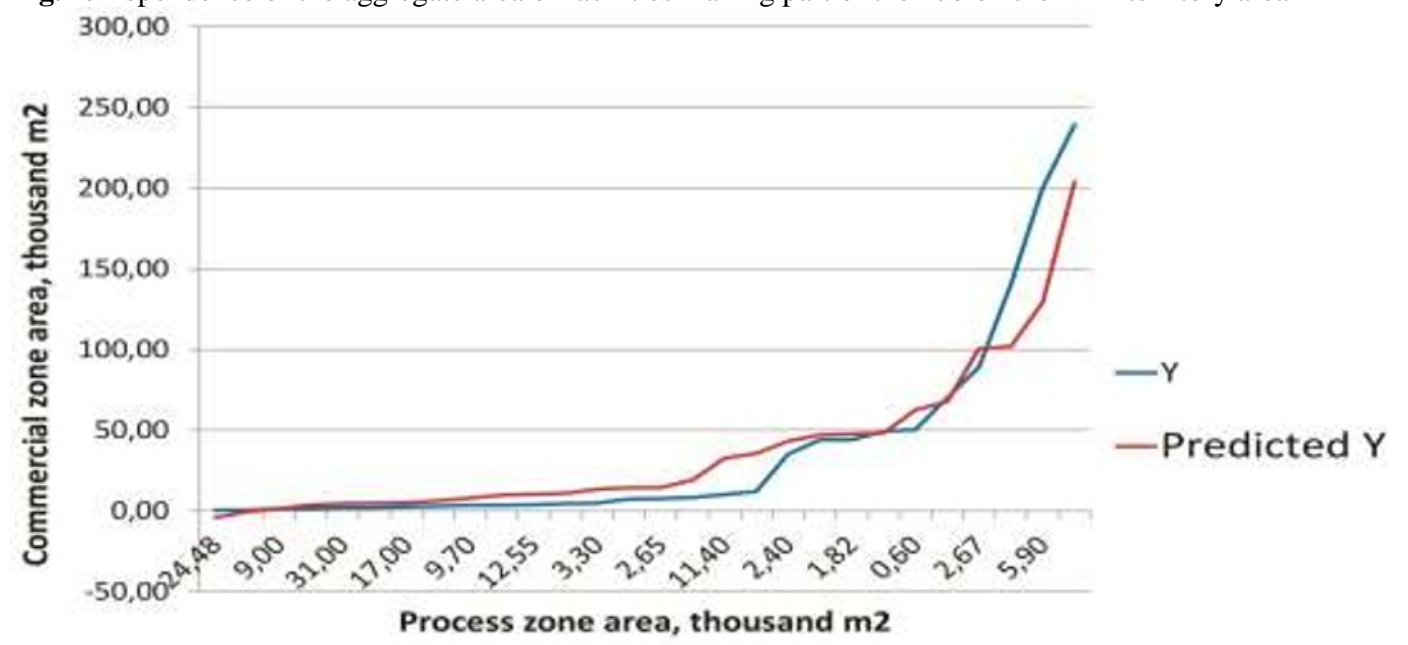

Fig. 5. Dependence of the commercial zone area on the process zone area

In these dependences, the multiple $\mathrm{R}$ coefficient is above 0.72 , which evidences a strong interconnection between the dependent and the independent variables.

The calculation data are shown as diagrams in Fig. 2 to 5.

Pursuant to the performance diagrams, it can be seen that the predicted projected dependent variable $Y$ takes values below 0 , which is impossible, as $Y$ means the area of a territory. Therefore, minimum parameters of the independent variable should be introduced. The considered dependences take the form of quadratic equations, thus, the minimum value of the area will be a positive equation root.

Minimum area values:

- Dependence of the commercial zone area on the TTH territory area $-\mathrm{x}_{\min }=1.9$ ha. This means that if a TTH territory is less than 1.9 ha, the deployment of commercial areas is unreasonable.

- Dependence of the aggregate area of TTH facilities on the TTH territory area $x_{\min }=1.5$ ha. If a TTH territory is less than 1.5 ha, the deployment of TTH 
facilities is unreasonable (i.e. the "2D" layout solution of the TTH without deployment of any major facilities is the most reasonable option).

\section{Discussion}

Key weaknesses of the above study follow from its strengths, i.e. from the exploratory framework - transfer hub layout designs approved but not yet implemented. Without seeing the implementation of the solutions in question, and in the lack of urban project quality assessment procedures, it is hard to evaluate the efficiency, convenience and benefit of the said solutions. Moreover, in many cases, the domination of the developer's interests in considering territory development options cannot be denied.

Still, the existence of regular patterns shows that this field in the study of transfer hubs is quite promising. The monitoring of layout designs developed and approved should be continued. Moreover, the accuracy of data can be improved, if not only projects prepared for Moscow region, but also for other regions are considered.

\section{Conclusions}

1. Further studies are required, based on the monitoring of approved territory planning documents, and as far as transfer hubs are completed - based on the evaluation of results obtained against those projected in planning designs.

2. A theoretical transfer hub model should be elaborated, which would consider not only the transport and urban planning, but also social and economic requirements. Subsequently, the model can be used as the basis for calculations in planning designs, to determine the limit parameters of the transfer hub territory development.

3. A list of technical facilities should be generated, which should (or are recommended to) be put in place within the transfer hub area intended for deployment of facilities (such as «incentive» parking lots [16, 17 et al.]).

4. Subsequently, the data of this study can be used as a basis for elaboration of Regional urban planning guidelines for transfer hubs of Moscow region, and further - for federal Transfer hub designing regulations.

\section{References}

1. Azarenkova, Z.V. Planning organization of transport hubs / W.V. Azarenkova // Academia. Architecture and construction - 2011. - 4 - p. 76.

2. Vakulenko, S.P. The planning structure of transport hubs / SP Vakulenko, N.Yu. Evreenova // World of Transport. - 2012. - 5. - p. 100.

3. Vlasov D.N. Improving the efficiency of transport interchange hubs in large cities // "Real Estate: Economy, Management",1, 2011,p. 57 - 61

4. Danilina N. Intermodal system for the Russian Federation: reality and forecast // In the collection: E3S Web of Conferences Ser. "International Conference on Sustainable Cities, ICSC 2016" 2016. P. 02001.

5. Information materials of the Moscow Region Government: official information. Officer Site of the Moscow Region Government. - [Electronic resource]. - Access mode: http://www.mosreg.ru/.

6. Information materials of the Government of Moscow: official. information. - Officer Moscow Government website. - [Electronic resource]. - Access mode: https://www.mos.ru. 
7. SP 42.13330.2011 Code of Practice. Town planning. Planning and development of urban and rural settlements. Updated version of SNiP 2.07.01 - $89 *$ [approved. Order of the Ministry of Regional Development of the Russian Federation dated December 28, 2010 No. 820]. - [Electronic resource]. - Access mode: http://www.minstroyrf.ru/docs/1947/?sphrase_id=621735.

8. Reconstruction and updating of the existing buildings of the city: a textbook. 2nd ed., Pererab. and ext. // under ed. P.G. Grabovogo, V.A. Kharitonov - Moscow: Prospect, $2013-712 \mathrm{~s}$

9. Solunsky AI, Manukhina L.A. Criteria for assessing the residential attractiveness of territories during the reconstruction and renovation of the existing urban development // Real Estate: Economics, Management. 2010. No. 3-4. Pp. 51-55

10. Kazarnovsky V.A., Manukhina L.A. Ecological comfort of residential area // In the collection: Social and economic problems of urban planning and architecture Proceedings of the Tenth All-Russian and Eighth International Scientific and Practical Conference. Editors: Barsukova T.I., Liseev I.K., Salmina N.G., 2011. P. 142-148

11. Vlasov D.N. Transplant in Japanese // Architecture and Construction of Moscow, No. 2, 2010, p. 22-28

12. Vlasov D.N. The structure and composition of regulatory requirements for urban transport hubs // Urban Planning, 3 (37), 2015 p. 11 - 19

13. Regression in Excel: equation, examples. Linear regression - [Electronic resource] Access mode: http://fb.ru/article/322644/regressiya-v-excel-uravnenie-primeryilineynaya-regressiya.

14. The concept of linear regression. Paired linear regression - [Electronic resource] Access mode: https://function-X.ru/statistics_regression1.html.

15. Regression analysis: concept, objectives, main goals - [Electronic resource] - Access mode: https://lektsii.org/14-76878.html.

16. Vlasov Denis, Danilina Nina. The Scientific and Methodological Development of the Park-and-Ride Facilities in the Intermodal Transport Hubs of Moscow Agglomeration // Advanced Materials Research Vols. 869-870 (2014) pp 201-204 (C) (2014) Trans Tech Publications, Switzerland doi: 10.4028 / www.scientific.net / AMR.869-870.201

17. Danilina N., Elistratov D. Organization of municipal transport access control system.passenger service models // Collection: Transportation Research Procedures 2017 